Int. Arch. Allergy 1969;36:I-XVIII

\title{
Contents, Vol. 36, 1969
}

International Archives of

Allergy and Applied Immunology

Incorporating the Transactions of the Collegium Internationale

Allergologicum

Founders: D. Harley, P. Kallós, W. Löffler, Fred. W. Wittich

Editors-in-Chief

R. R. A. Coombs, Cambridge

H. C. Goodman, Geneva

F. Fiahn, Freiburg/Br.

P. Kallós, Helsingborg

F. Milgrom, Buffalo, N.Y.

G. B. West, Carshalton, Surrey

Contributing Editors

E. L. Becker, Washington, D.C.

H. Bloch, Basel

W. E. Brocklehurst, Edinburgh

T. Broman, Göteborg

L. Businco, Roma

A. Cerletti, Basel

A. L. De Weck, Bern

P. G. H. Gell, Birmingham

I. Glazer, Tel Aviv

R. A. Good, Minneapolis, Minn.

A. Grumbach, Zurich

M. Hasek, Prague

T. Inderbitzin, Miami, Fla.

H. Isliker, Lausanne

E. A. Kabat, New York

W. Kaufmann, Bridgeport, Conn.

R. Keller, Zurich

P. Miescher, Geneva

T. Ogata, Tokyo

A. Oliveira-Lima, Rio de Janeiro

Ö. OUCHTERLONY, Göteborg

W. Pagel, London

R. Panzani, Marseille

M. Rocha e Silva, São Paulo

I. M. Roitt, London

B. Rose, Montreal 
D. Rowe, Geneva

G. Ruiz-Moreno, Buenos Aires

E. Sorkin, Davos-Platz

H. Storck, Zurich

A. Szenberg, Geneva

A. Tiselius, Uppsala

Z. Trnka, Geneva

B. H. Waksman, New Haven, Conn.

G. L. Waldbott, Detroit, Mich.

R. G. White, London

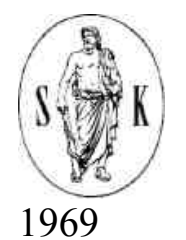

Vol. 36

BASEL (Switzerland) S. KARGER NEW YORK

All rights, including that of translation into other languages, reserved.

Photomechanic reproduction (photocopy, microcopy) of this book or parts thereof without special permission of the publishers is prohibited.

(C)

Copyright 1969 by S. Karger AG, Basel Printed in Switzerland by Buchdruckerei NationalZeitung AG, Basel

Contents

Aaronson, D.; Patterson, R.; Wennmeark, J. and Lev, M.: Biologic Effects of

Heterologous Antisera to Canine Heart 523

Aas, K.: Antigens and Allergens of Fish 152

Aho, K.: vide Lassus, A.

Alvord, E. C.: vide Hruby, Sarka

Ashkenazi, A.: vide Glazer, I.

Balas, L.: vide Lass, N.

Ben-Efraim, S. and Torten, M.: Hypersensitivity Reactions in Experimental Leptospirosis 216

Ben-Efraim, S.: vide Kohn, A.

Berg, T. and Johansson, S. G. O.: IgE Concentrations in Children with Atopic

Diseases. A Clinical Study 219

Bertilsson, G.: vide Pedersen, N. Bang

Bethge, K. P.: vide Schmutzler, W.

Björklund, B.: Systematic Antigenic Change in Human Carcinoma Tissues by Hemagglutínation Techniques

Bonhomme, F.; Boucheron, C; Migliore, D. and Jollès, P.: Arthritogenicity of

Unaltered and Acetylated Cell Walls of Mycobacteria 317

Boucheron, C.: vide Bonhomme, F.

Braley, Helen C: vide Freeman, M. J.

Chan, P. C. Y.: Immunosuppressive Action of Phytohemagglutinin. Effect on

Peritoneal Macrophages 486 
Comas, F. V.: vide Lozzio, B. B.

Coombs, R. A.: vide Hunter, A.

Coombs, R. R. A.: vide Lachmann, P. J.

Diamant, B.: The Influence of Adenosine Triphosphate on Isolated Rat Peritoneal Mast Cells 3

Dietrich, F. M. and Dukor, P.: Further Studies on Chemically Induced Tolerance to Heterologous Red Cells in Mice 91

Dingle, J. T.: vide Lachmann, P. J.

Dukor, P.: vide Dietrich, F. M.

Duncan, Jessie G. C. and Waton, N. G.: Further Studies on the Origin of Tissue Histamine, with Special Reference to Intestinal Absorption 31

Ehe, L.: vide Lippert, T. H.

Ehnholm, C: Subtyping Haptoglobins with Precipitating Antisera. Part II . . 427

Espino, E. B.: vide Manski, W.

Contents

Fell, Honor B.: vide Lachmann, P. J.

Ferraresi, R. W.: vide Goihman-Yahr, M.

Ferber, E.: vide Munder, P. G.

Fischer, H.: vide Munder, P. G.

Freedman, B. J.; Meisner, P. and Hill, G. B.: A Comparison of the Actions of Different Bronchodilators in Asthma 186

Freeman, M. J.; Braley, Helen C.; Kaplan, A. M. and McArthur, W. P.:

Occurrence and Properties of Rabbit Homocytotropic Antibody 530

Fregert, S.: vide Pedersen, N. Bang.

Frei, P. C.: Further Characterization of Immune Tolerance Obtained in Adult

Rabbits with Non-Immunogenic BSA. Attempts at Passive Transfer.... 103

Fujiwara, Y.: vide Ishibashi, T.

Gajl-Peczalska, K.; Meuwissen, H. J. and Good, R. A.: Pokeweed Mitogen

Induced Blastoid Transformation in Purified and Non-Purified Leukocyte

Cultures $\quad 546$

Gewurz, H.; Pickering, R. J.; Naff, G.; Snyderman, R.; Mergenhagen, S. E. and Good, R. A.: Decreased Properdin Activity in Acute Glomerulone-

phritis 592

Giertz, H. and Hahn, F.: Mechanism of Histaminase Liberation in Guinea Pig

Anaphylaxis 41

Glazer, I.: Etiologic Factors of Bronchial Asthma in Israel 172

Glazer, I.; Ashkenazi, A. and Magora, F.: Electrosleep Therapy in Bronchial

Asthma 163

Goihman-Yahr, M.; Raffel, S. and Ferraresi, R. W.: Cross Reactivities of

Lepromin $\quad 450$

Goldschmidt, O.: vide Schmutzler, W.

Goldstein, G. B.; Underdown, B. J.; Heiner, D. C.; Rose, B. and Goodfriend, L.:

Isolation of Antibodies to Gliadin and Ragweed Antigen E with the Use of

Immunosorbents 573

Gold, D.: vide Tager, A.

Good, R. A.: vide Gajl-Peczalska, K. 
Good, R. A.: vide Gewurz, H.

Good, R. A.: vide Lemmel, E. M.

Good, R. A.: vide Rodey, G. E.

Goodfriend, L.: vide Goldstein, G. B.

Gordon, E. B.: vide Wiener, A. S.

Greaves, M. W.: The Effect of Disodium Cromoglycate and other Inhibitors on

in vitro Anaphylactic Histamine Release from Guinea Pig Basophil Leucocytes 497

Haferkamp, O.; Schäfer, H.; Wessel, W. and Hsu, K. C.: Studies of the Antigen-

Antibody Reaction by Electron Microscopy. I. On the Transfer of Aggluti

nating Antibodies from Sensitized Sheep Erythrocytes to Freshly Added

(Unsensitized) Red Blood Cells 298

Haferkamp, O.: vide Sodomann, C. P.

Contents

Hahn, F.: vide Giertz, H.

Haimovich, J.: Detection of Anti-Penicilloyl Antibodies by the Inactivation of

Penicilloylated Tt Bacteriophage 140

Heiner, D. C.: vide Goldstein, G. B.

Helering, I.: vide Kohn, A.

Hill, G. B.: vide Freedman, B. J.

Hruby, Sarka; Alvord, E. C. and Shaw Cheng-Mei: Relationships between

Antibodies and Experimental Allergic Encephalomyelitis. I. Production of

Hemagglutinating and Gel-Precipitating Antibodies in Rabbits and Guinea

Pigs 599

Hsu, K. C.: vide Haferkamp, O.

Hunter, A. and Coombs, R. R. A.: Red Cell Linked Antigen-Antiglobulin Reaction.

Studies on the Preparation of Red Cell Antibody-Coupled Antigen Reagents 354

Ishibashi, T.; Fujiwara, Y.; Tanaka, A. and Sugiyama, K.: Antigenicity of Wax

D. IV. Its Relationship to other Hemagglutination Reactions 506

Ishibashi, T.: vide Koga, T. Johansson, S. G. O.: vide Berg, T. Jollès, P.: vide Bonhomme, F.

Kaplan, A. M.: vide Freeman, M. J. Kasemir, H.: vide Kerp, L.

Kasukawa, R.; Yoshida, T. and Milgrom, F.: An Isoprecipitin Distinguishing

Polymorphism of Human Serum at Globulin 347

Keller, R.: Presents Status of Biochemical and Pharmacological Analysis of

Secondary Cellular Damage in Antibody-Mediated Allergic Reactions . . 56

Kerp, L.; Kasemir, H.; Kieling, F. and Steinhilber, S.: Localisation of Antibody-

Binding Sites on Insulin Molecules 143

Kieling, F.: vide Kerp, L. Knop, J.: vide Schmutzler, W.

Koga, T.; Ishibashi, T.; Sugiyama, K. and Tanaka, A.: Immunological Ad

juvants. III. A Preliminary Report about the Mode of Action of Mycobacte-

rial Adjuvants and Further Confirmation of Adjuvant Activity of Acetylated

WaxD. 233

Kohn, A.; Helering, I. and Ben-Efraim, S.: Adjuvant Properties of Alginate in

Bacterial, Viral and Protein Vaccines $\quad 156$

Krogh, H. K.: Antibodies in Human Sera to Stratum corneum 
Lachmann, P. J.; Coombs, R. R. A.; Fell, Honor B. and Dingle, J. T.: The Break down of Embryonic (Chick) Cartilage and Bone Cultivated in the Presence of Complement-Sufficient Antiserum. III. Immunological Analysis 469

Lass, N.: vide Tager, A.

Lass, N.; Laurian, L. and Balas, L.: Evaluation of Metopiron and ACTH Tests in Prolonged Corticosteroid Treatment of Chronic Asthma 180

Lassus, A.: Development of Rheumatoid Factor Activity and Cryoglobulins in Pri mary and Secondary Syphilis 515

Lassus, A.; Salo, O. P. and Aho, K.: Anamnestic Reactions in Syphilis Serology 394

Contents

Laurian, L.: vide Lass, N.

Lemmel, E. M. and Good, R. A.: Immunosuppressive Action of Mitomycin C on

Lymphoid Cells. I. Effect on Cell-Mediated Immunity after in vitro Treatment,

Tolerance Induction, and Recovery in vivo 554

Lengy, J.: vide Tager, A.

Lev, M.: vide Aaronson, D.

Lidén, K.: vide Pedersen, N. Bang.

Lippert, T. H. and Ehe, L.: The Excretion of Histamine and Histamine Metabolites

by the Kidney and Gastrointestinal Tract of the Rabbit 290

Lozzio, B. B. and Comas, F. V.: Biological Effects of Pokeweed Mitogen 266

Magora, F.: vide Glazer, L:

Manski, W.; Espino, E. B. and Smelser, G. K.: Immunogenic Inflammation Caused by Soluble and Particulate Antigens of Corresponding Specificity. I. Reactions

in Actively Immunized Animals 376

McArthur, W. P.: vide Freeman, M. J.

Meisner, P.: vide Freedman, B. J.

Mergenhagen, S. E.: vide Gewurz, H.

Meuwissen, H. J.: vide Gajl-Peczalska, K.

Migliore, D.: vide Bonhomme, F.

Milgrom, F.: vide Kasukawa, R.

Modolell, M.: vide Munder, P. G.

Moor-Jankowski, J.: vide Wiener, A. S.

Munder, P. G.; Ferber, E.; Modolell, M. and Fischer, H.: The Influence of

Various Adjuvants on the Metabolism of Phospholipids in Macrophages . . 117

Nachtigal, D.: The Kinetics of Induction of Immune Tolerance in X-Rayed Rabbits 89

Naff, G.: vide Gewurz, H.

Naor, D. and Sulitzeanu, D.: Binding of 125I-BSA to Lymphoid Cells of Tolerant

Mice 112

Ovary, Z.: vide Revoltella, R.:

Packalén, T.: vide Wasserman, J.

Parish, W. E.: Detection of Reagins, IgG, IgA and IgM Antibodies in Human Sera 245

Patterson, R.: vide Aaronson, D.

Pedersen, N. Bang ; Bertilsson, G.; Fregert, S.; Lidén, K. and Rorsman, H.:

Disappearance of Chromium Injected Intracutaneously

Perlmann, H.: vide Wasserman, J.

Perlmann, P.: vide Wasserman, J. 
Pickering, R. J.: vide Gewurz, H.

Polák, L. and Turk, J. L.: The Effect of Antihypertensive Agents on the Peripheral Manifestation of Allergic and other Inflammatory Reactions in the Skin . 442

Polák, L.: vide Turk, J. L.

Raffel, S.: vide Goihman-Yahr, M.

Contents

Revoltella, R. and Ovary, Z.: Preferential Production of Rabbit Reaginic Anti bodies 282

Rife, U.: Antigenically-Induced Changes in Lymph Nodes during the Primary Anti body Response 538

Rodey, G. E. and Good, R. A.: The in vitro Response to Phytohemagglutinin of Lymphoid Cells from Normal and Neonatally Thymectomized Adult Mice 399

Rorsman, H.: vide Pedersen, N. Bang

Rose, B.: vide Goldstein, G. B.

Rosenfeld, E.: vide Schwartz, Jeanna.

Rutman, Nilly : vide Schwartz, Jeanna.

Salo, O. P.: vide Lassus, A.

Schäfer, H.: vide Haferkamp, O.

Schmutzler, W.; Goldschmidt, O.; Bethge, K. P. and Knop, J.: The Release of

Guinea Pig Liver Histaminase and some of its Properties 45

Schneider, C. H, and Weck, de A. L.: Immunochemical Aspects of Penicillin

Chemistry 129

Schneider, C. H.: vide Weck, de A. L.

Schwartz, Jeanna ; Rutman, Nilly ; Vardinon, Nurith and Rosenfeld, E.:

Serological Adhesion in Chicken and Mammalian Cultures with Human

Erythrocytes of Different Reactivity 204

Shaw, Cheng-Mei: vide Hruby, Sarka

Shellam, G. R.: vide Wistar, R. Jr.

Smelser, G. K.: vide Manski, W.

Snyderman, R.: vide Gewurz, H.

Sodomann, C. P. and Haferkamp, O.: Macrophage Cytophilic Antibodies to Tuberculoprotein in Rats Immunized with Bacillus Calmette Guérin 566

Steinhilber, S.: vide Kerp, L.

Sugiyama, K.: vide Ishibashi, T.

Sugiyama, K.: vide Koga, T.

Sulitzeanu, D.: Antigenic Structure of Connective Tissue 114

Sulitzeanu, D.: vide Naor, D.

Tager, A.; Lass, N.; Gold, D. and Lengy, J.: Studies on Culex pipiens molestus in Israel. IV. Desensitization Attempts on Children Showing Strophulus-Like

Skin Eruptions Following Bites of the Mosquito 408

Tanaka, A.: vide Ishibashi, T.

Tanaka, A.: vide Koga, T.

Telford, J. M.: Hormonal Influences on Mediators of Allergic Reactions ....

Tizard, I. R.: Macrophage Cytophilic Antibody in Mice. Differentiation between Antigen Adherence due to these Antibodies and Opsonic Adherence . , . 332

Torten, M.: vide Ben-Efraim, S. 
Turk, J. L. and Polák, L.: Experimental Studies on Metal Dermatitis in Guinea Pigs 75

Turk, J. L.: vide Polák, L.

Contents

Underdown, B. J.: vide Goldstein, G. B.

Vardinon, Nurith : vide Schwartz, Jeanna.

Wasserman, J.; Packalén, T.; Perlmann, P. and Perlmann, H.: Cytotoxic

Lymphoid Cells and Antibodies from Guinea Pigs Immunized with Tubercle

Bacilli 115

Waton, N. G.: vide Duncan, Jessie G. C.

Weck, de A. L. and Schneider, C. H.: Some Observations on the Molecular

Mechanisms of Immediate-Type Allergic Reactions

62

Weck, de A. L.: vide Schneider, C. H.

Wennmeark, J.: vide Aaronson, D.

Wessel, W.: vide Haferkamp, O.

West, G. B.: Kinins and Resistance to Thermic Oedema

Wiener, A. S.; Moor-Jankowski, J. and Gordon, E. B.: The Specificity of Hemagglutinatíng Bean and Seed Extracts (Lectins). Implications for the Nature of

A-B-H Agglutinins 582

Willoughby, D. A.: Mediators of Delayed Hypersensitivity Reactions

Wistar, R. Jr. and Shellam, G. R.: Immunoglobulin Levels during Thoracic Duct

Drainage in the Rat 323

Yoshida, T.: vide Kasukawa, R.

Book Reviews 321, 612

News Items 614

Edited by R.R. A.Coombs (Cambridge), D.Harley (London), P.Kallós (Helsingborg) and

G.B.West (Carshalton, Surrey)

With 80 figures and 47 tables

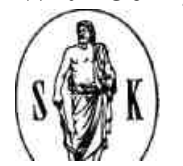

$19 \times \wedge \mathrm{t} \times 69$

BASEL (Switzerland) S. KARGER NEW YORK

Published simultaneously as Vol. 36, No. 1-2 (1969)

International Archives of Allergy and Applied Immunology

Transactions of the Collegium Internationale ÂHergologicum

1st Symposium in London, 1954. Aspects of Allergy Research. Edited by D. Har-ley (London) and P. Kallós (Helsingborg). 203 p., 66 fig., 1955. (Separatum vol. 6, fasc. 4-6 International Archives of Allergy and Applied Immunology.)

sFr.27.-

2nd Symposium in Basel, 1955. Migraine and Vascular Allergy. Edited by R.R. A.

Coombs (Cambridge), D.Harley (London) and P.Kallós (Helsingborg).

IV+356 p., 136 fig., 1956. (Separatum vol. 7, fasc.4-6, and vol.8, fasc. 1-2

International Archives of Allergy and Applied Immunology.) sFr. 39.50

3rd Symposium in London, 1957. Dermatological and Serological Aspects of Allergy. Edited by

R.R.A.Coombs (Cambridge), D.Harley (London) and P.Kallós (Helsingborg). IV+240 p., 137 
fig., 1958. (Separatum vol. 11, fasc. 1-4 International Archives of Allergy and Applied Immunology.) sFr. 36.-

4th Symposium in Rome, November 1959. Current Trends in Allergy - Types of Allergic Reactivity - Bronchial Asthma. Edited by D.Harley (London),

P.Kallós (Helsingborg) and G.B. West (London). IV+240 p., 65 fig., 12 tab., 1961. (Separatum vol. 18, fasc. 1-4 International Archives of Allergy and Applied Immunology.) SFr. 36.-

5th Symposium in Freiburg i.Br., October 1962. Recent Advances in Allergy Research. Edited by H.Hahn (Freiburg i.Br.), P.Kallós (Helsingborg) and G.B.West (London). IV+355 p., 117 fig., 43 tab., 1963. (Separatum vol.22, No. 2,3-4,5,6 International Archives of Allergy and Applied Immunology.)

sFr.55.-

6th Symposium in London, September 1964. Recent Advances in Allergy and Immunology. Edited by D.Harley (London), P.Kallós (Helsingborg) and G.B.West (London). IV+140 p., 39 fig., 16 tab., 1965. (Separatum vol.28, No. 1-3 International Archives of Allergy and Applied Immunology.) sFr. 27.-

S. Karger AG, Arnold-Böcklin-Strasse 25, 4000 Basel 11 (Switzerland)

All rights, including that of translation into other languages, reserved.

Photomechanic reproduction (photocopy, microcopy) of this book or parts thereof without special permission of the publishers is prohibited.

(C)

Copyright 1969 by S. Karger AG, Basel Printed in Switzerland by Basler Druck- und Verlagsanstalt, Basel

Collegium Internationale Allergologicum

Officers

President:

Vice-President:

Honorary Secretary:

Executive Secretary- Treasurer:

President-elect:

Honorary-Secretary-elect:

Members of Council:

D. Harley

J. DUGHAINE

P. Kallós

A. Cerletti

G.B.West

A. de Weck

R.R. A. Coombs (1964)

L.E.Glynn (1968)

F.Sicuteri

A.deWeck (1968)

I.Glazer (1968)

M. Loveless (1964)

J.Turk (1968)

R.G. White (1964) 
Membership Directory

Argentina *Dr. M. A. Solari, 1219 Carlos Pellegrini, Buenos Aires

Australia

*Dr.R.H.O.Donald, 72 Beach Road, Hampton (Victoria) C *Dr. B. M. B. Riley, 143 Macquarie Street, Sydney C *Dr. R. S. Steel, 135 Macquarie Street, Sydney

Dr. P. C. G. Waugh, 41 Hunter Street, Parramatta (N.S.W.)

Austria

Prof. W. Lindemayr, Dermatological Clinic, Wilhelminenspital, 1090 Wien Prof. E. Pichler, Elisabethenstrasse 23, Graz

Prof. C. Steffen, Institut für Immunologie der Universität Wien, Borschkegasse 8 a, 1090 Wien Belgium

P.D. Dr. L. Craps, Soc. Anon. Ciba, Grand-Bigard *Dr. J. Duchaine, 102 Av. Emile de Béco, Bruxelles Dr. A. Ferrière, Clinic « Saint-Pierre», Ottignies Dr. J.Jamar, 52 Boul. de la Cambre, Bruxelles C Prof. J. Lecomte, 11 Rue Blès, Liege

Dr. J. Salmon, Institut de Médecine, Université de Liège, Liège Dr. R. Spapen, 311, Avenue Kersbeck, Bruxelles 18

Brazil C Prof. O.G. Bier, Dep. of Bacteriology and Immunology, Escola Paulista de Medicina, Caixa Postal 7144, São Paulo

Canada

Dr. M. Richter, Div. of Immunochemistry, Royal Victoria Hospital, 687 Pine West, Montreal 2 *Prof. H. Selye, Univ. of Montreal, P.O.B.6128, Montreal

IV

Collegium Internationale Allergologicum

Czechoslovakia Prof. V. Hlavacek, Nove Mesto, Pricna 1, Praha 1

Denmark C Dr. T. Dalsgaard-Nielsen, 4, Vestre Boulevard, Copenhagen V

DDR (East Germany)

Dr. D. G. R. Findeisen, Fachkrankenhaus Mahlow, Mahlow (Bez. Potsdam)

Prof. W. Hollmann, Medizinische Klinik, Potsdam

Prof. A. Sylla, Medizinische Klinik des Stadtkrankenhauses, Cottbus

Finland Dr. J. Alberty, c/o Lääketehdas Orion, P. Y. Nilsiänkatu 10-14, Helsinki

France

*Dr. P. Blamoutier, 5 Rue de Luynes, Paris 7 Dr. J. Cany, 10 Rue de Castiglione, Paris 1 Dr.

E.Hénocç¿, 131 Boul. Malesherbes, Paris 17 Dr. J. R. Mallet, 9 Cours Balguerie-Stuttenberg, Bordeaux Dr. R. Panzani, 27A Rue Edouard Delanglade, Marseille 6 C *Prof. Pasteur ValleryRadot, 49bis Av. Franklin D. Roosevelt, Paris 8 Dr. J. Sclafer, 3 Rue Albéric Magnard, Paris 15 Germany (Bundesrepublik Deutschland)

Prof. H.Fischer, Max-Planck-Institutfür Immunbiologie, Stübeweg 51,

78 Freiburg-Zähringen

Dr. E. Fuchs, Kurparkstrasse 3, 4792 Bad Lippspringe, Westfalen

Prof. H. Giertz, Pharmakologisches Institut der Universität, Katharinen-

strasse 29, 78 Freiburg i.Br.

Prof. W. Gronemeyer, Arminiuspark 3, 4792 Bad Lippspringe, Westfalen C *Prof. F. Gross, Pharmakologisches Institut der Universität, 69 Heidelberg

Prof. F. Hahn, Pharmakologisches Institut der Universität, Katharinenstrasse 29, 78 Freiburg i. Br.

Dr. L.Kerp, Medizinische Klinik der Universität, 78 Freiburg i.Br. 
Prof. P. Klein, Bakteriologisches Institut der Universität, 65 Mainz

Prof. H. Kleinsorge, Wilhelmstrasse 52 E/450, 62 Wiesbaden

Prof. E. Letterer, Pathologisches Institut der Universität, 74 Tubingen

Prof. H. Schadewaldt, Mediz $1 / 8$ historisches Institut der Universität,

Moorenstrasse 5, 4 Düsseldorf C Prof. F. Scheiffarth, Abt. für klinische Immunologie der

Medizinischen

Klinik der Universität, 852 Erlangen

P.D. Dr. W. Schmutzler, Pharmakologisches Institut der Universität, Katha-

rinenstrasse 29, 78 Freiburg i.Br.

Prof. M. Werner, Medizinische Klinik des Kreiskrankenhauses,

208 Pinneberg

Prof. O.Westphal, Max-Planck-Institut für Immunbiologie, Stübeweg 51,

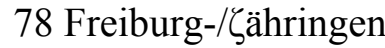

Contents

Membership-Directory of the Collegium Internationale Allergologicum . . . Ill

West, G. B. (Carshalton, Surrey): Kinins and Resistance to Thermic Oedema

Diamant, B. (Stockholm): The Influence of Adenosine Triphosphate on Iso

lated Rat Peritoneal Mast Cells

3

Willoughby, D.A. (London): Mediators of Delayed Hypersensitivity Reac

tions 22

Telford, J.M. (Brighton): Hormonal Influences on Mediators of Allergic

Reactions 29

Duncan, Jessie G. C. and Waton, N. G. (Glasgow): Further Studies on the Origin of Tissue

Histamine, with Special Reference to Intestinal Absorption 31

Giertz, H. and Hahn, F. (Freiburg i.Br.): Mechanism of Histaminase Libera

tion in Guinea Pig Anaphylaxis 41

Schmutzler, W.; Goldschmidt, O.; Bethge, K. P. and Knop, J. (Freiburg

i.Br.): The Release of Guinea Pig Liver Histaminase and Some of Its

Properties 45

Keller, R. (Zurich): Present Status of Biochemical and Pharmacological

Analysis of Secondary Cellular Damage in Antibody-Mediated Allergic

Reactions 56

Weck, A. L. De and Schneider, C. H. (Bern): Some Observations on the

Molecular Mechanisms of Immediate-type Allergic Reactions 62

Turk, J. L. and Polák, L. (London): Experimental Studies on Metal Dermatitis

in Guinea Pigs 75

Pedersen, N. Bang ; Bertilsson, G.; Fregert, S.; Lidén, K. and Rorsman, H.

(Lund): Disappearance of Chromium Injected Intracutaneously .... 82

Nachtigal, D. (Rehovoth): The Kinetics of Induction of Immune Tolerance

in X-Rayed Rabbits 89

Dietrich, F. M. and Dukor, P. (Basel): Further Studies on Chemically Induced

Tolerance to Heterologous Red Cells in Mice 91

Frei, P. C. (Lausanne): Further Characterization of Immune Tolerance

Obtained in Adult Rabbits with Non-Immunogenic BSA. Attempts at

Passive Transfer 103

Naor, D. and Sulitzeanu, D. (Jerusalem): Binding of 125I-BSA to Lymphoid 
Cells of Tolerant Mice

112

Sulitzeanu, D. (Jerusalem): Antigenic Structure of Connective Tissue ... 114

Wasserman, J.; Packalén, T.; Perlmann, P. and Perlmann, H. (Stockholm):

Cytotoxic Lymphoid Cells and Antibodies from Guinea Pigs Immunized

with Tubercle Bacilli 115

Munder, P.G.; Ferber, E.; Modolell, M. and Fischer, H. (Freiburg i.Br.):

The Influence of Various Adjuvants on the Metabolism of Phospholipids in

Macrophages 117

Schneider, C.H. and Weck, A.L. De (Bern): Immunochemical Aspects of

Penicillin Chemistry 129

Haimovich, J. (Rehovoth): Detection of Anti-Penicilloyl Antibodies by the

Inactivation of Penicilloylated T4 Bacteriophage 140

Kerp, L.; Kasemir, H.; Kieling, F. and Steinhilber, S. (Freiburg i.Br.):

Localisation of Antibody-binding Sites on Insulin Molecules 143

Aas, K. (Oslo): Antigens and Allergens of Fish 152

Kohn, A.; Helering, I. and Ben-Efraim, S. (Ness Ziona): Adjuvant Properties

of Alginate in Bacterial, Viral and Protein Vaccines 156

Collegium Internationale Allergologicum

$\mathrm{V}$

Great Britain

Honorary Members: Prof. J.R.Marrack, Cambridge

Dr. R. Augustin, Immunology Research Unit, Nuffield Wing, Medical

School, Crown Street, Liverpool 7 C *Dr. C.J.Britton, 35 Harley Street, London, W.1

Dr. W. E. Brocklehurst, The Lilly Research Laboratories, Windlesham,

Surrey

Dr. R. A. Bruce, Redlands, Rupert Road, Middleton, Ilkley, Yorkshire

Prof. CD. Calnan, St. John's Hospital for Diseases of the Skin, Lisle Street,

Leicester Square, London, W. C. 2 C * Prof. R. R. A. Coombs, Department of Pathology of the

University, Tennis

Court Road, Cambridge

Dr. J.G. Feinberg, The Miles Laboratories, Stoke Court, Stoke Poges,

Slough, Bucks. C *Dr. W. Feldberg, National Institute for Medical Research. The Ridgeway,

Mill Hill, London, N.W.7

Prof. P. G.H.Gell, Department of Experimental Pathology, The Medical

School, The Hospitals Centre, Birmingham 15

Dr. L. E. Glynn, Med. Res. Council Rheumatism Research Unit, Canadian Red

Cross Memorial Hospital, Taplow, Maidenhead, Berks. *Dr. D. Harley, 72, Ducks Hill,

Northwood, Middlesex

Dr. J.H.Humphrey, National Institute for Medical Research, The Ridgeway,

Mill Hill, London, N. W.7 C Dr. D. Leigh, The Maudsley Hospital, Denmark Hill, London,

S.E.S.

Dr. F.H.Milner, Bencard Allergy Division, Great West Road, Brentford,

Middlesex C *Dr. W. Pagel, 58 Millway, London, N. W. 7 C Prof. W. Paton, Department of

Pharmacology of the University, Oxford

Prof. J.Pepys, Department for Immunology, Institute of the Diseases of the 
Chest, Brompton, London, S. W. 3 C *Prof. Sir George W.Pickering, Radcliffe Infirmary, Oxford C *Prof. C.Rimington, Department of Chemical Pathology, University College Hospital, Gower Street, London, W. C. 1

Prof. H. O. Schild, Department of Pharmacology, University College Hospital, Gower Street, London, W. C. 1

Dr. J.L.Turk, Department of Immunology, St.John's Hospital for Diseases of the Skin, Lisle Street, Leicester Square, London, W. C. 2

Dr. N. G. Waton, Division of Pharmacology, Department of Pharmacy, University of Strathclyde, Glasgow, C. 1

Dr. G. B. West, BIBRA, Woodmansterne Road, Carshalton, Surrey

Prof. R. G. White, Department of Bacteriology of the University, Western Infirmary, Glasgow, W. 1

Dr. D. A. Willoughby, Department of Pathology, St. Bartholomew's Hospital

Medical School, London, E. C. 1

Dr. C.M.Wilson, Department of Pharmacology of the University, Trinity

College, Dublin 2

India

Prof. R. K. Sanyal, Department of Pharmacology, Maulana Azad Medical College, New Delhi Israel

Prof. M. Feldman, The Weizmann Institute of Science, Rehovoth Dr. I. Glazer, 89 Bograshow Street, Tel Aviv

VI

Collegium Internationale Allergologicum

Prof. M. Sela, The Weizmann Institute of Science, Rehovoth

Prof. B. Sulitzeanu, Department of Bacteriology, Medical School of the

University, Jerusalem

Prof. J.Tas, Department of Dermatology, Hadassah University Hospital,

Jerusalem

Italy C Prof. F. Antonelli, Via San Marino 36, Roma

Prof. L. Businco, Via aB de Rossi 15A, Roma

Prof. E. Fortunato, Via Barbiellini Amadei 43 (Pineta Sachetti), Roma C *Prof. CFrugoni, Via Bruxelles 47, Roma

Dr. U. Granelli, Hospital «San Gallicano», Roma

Prof. E. Greppi, Medical Clinic of the University, Firenze C *Prof. A. Lunedei, Via Guicciardini

2, Firenze C *Prof. G. Melli, Corso Italia 8, Milano C Prof. P. Sangiorgi, Centro clinico

antiasmatico-antiallergico, Bordíghera

Prof. F.Sicuteri, Medical Clinic of the University, Firenze

Japan C Prof. K. Higuchi, Dermatological Clinic, Kyushu University, Katakasu,

Fukuoka C *Prof. M. Maekawa, Medical Faculty, Kyoto University, Kyoto

Prof. T. Ogata, Ogata Institute for Medical and Chemical Research,

1-11 (4) Higashi-Kanda, Chiyoda/Tokyo

Netherlands *Prof. H. A. E. van Dishoeck, University Hospital, Leyden Jhr. Dr. W.J. Quarles van Ufford, 17 Emmalaan, Utrecht Dr. R. Voorhorst, University Hospital, Leyden

Norway Doc. Dr. Kjell Aas, Pediatric Department, Rigshospitalet-University Hospital, Oslo Poland C Prof. M. Obtulowicz, 9 Ul.Jagiellonska, Krakow 
South Africa C *Dr. D. Ordman, Institute for Medical Research, P. O. B. 1038, Johannesburg Dr. H. G. Goldwater, 103 Pasteur Chambres, Jeppe Street, Johannesburg Spain Dr. F. Lahoz, Institute for Clinical Investigations, Ciudad Universitaria, 2 Av. Reyes Catolicos, Madrid

\section{Sweden}

Dr. B. Björklund, State Laboratory for Bacteriology, P. O. B. 764,

10131 Stockholm

Dr. B. Diamant, Department of Pharmacology, Karolinska Institutet,

10401 Stockholm *Dr. P. Kallós, Sundstorget 3, 25221 Helsingborg *Dr. L. Kallós-Deffner, Sundstorget 3, 25221 Helsingborg

Collegium Internationale Allergologicum

VII

Prof. H.Koch, University Hospital, 22590 Lund

Prof. Ö. Ouchterlony, Department of Bacteriology of the University, Guldhedsgatan 10, 41320

Göteborg Dr. H. Rorsman, University Hospital, 22590 Lund C *Prof.J.WALDENSTRÖM,

Medical Clinic of the University of Lund, General Hospital, 20090 Malrnö

Switzerland

Prof. HJ.Bein, Ciba AG, 4000 Basel

Prof. H. Bloch, Ciba AG, 4000 Basel

P.D. Dr. A. Cerletti, Sandoz AG, 4002 Basel

P.D. Dr. M.Dietrich, Ciba AG, 4000 Basel

Dr. P.Dukor, Ciba AG, 4000 Basel

Dr. J. R. Frey, Hoffmann-La Roche AG, 4000 Basel

Dr. R. Hoigné, Zieglerspital, 3000 Bern

Dr. R.Jaç > ues, Ciba AG, 4000 Basel

Prof. W.Jadassohn, Dermatological Clinic of the University, 1200 Geneve

P.D. Dr. R.Keller, Dermatological Clinic of the University, Gloriastrasse 32,

8000 Zurich C *Prof. W. Löffler, Zürichbergstrasse 44, 8000 Zurich

Dr. E. Musso, Dermatological Clinic of the University, 1200 Geneve C *Prof. E.Rothlin,

Sonnenweg 6, 4000 Basel

Dr. C. H. Schneider, Department for Allergy and Immunology, Inselspital, 3008 Bern

Prof. R. Schuppli, Dermatological Clinic of the University, 4000 Basel C *Prof. A. Stoll, Bildstöckliweg 11, 4144 Arlesheim BL

Prof. H. Storck, Dermatological Clinic of the University, Gloriastrasse 32,

8000 Zurich

P.D. Dr. A.K. de Weck, Department for Allergy and Immunology, Inselspital, 3008 Bern

Turkey C Prof. A. Akcasu, Department of Pharmacology of the University, Istanbul USA

Dr. C.B. Favour, National Jewish Hospital, 3800 East Colfax, Denver, Col. 80220 Dr.

A.P.Friedman, Headache Unit, Montefiore Hospital, 210 Street and Bainbridge Avenue, Mew York, N. Y. 10016

Prof. R. A. Good, Variety Club Heart Hospital, Minneapolis, Minn. 55455 Dr. H. C. Goodman, Immunology Unit, World Health Organization, Avenue Appia, 1211 Geneve, Switzerland 
Prof. T. Inderbitzin, Dept. of Dermatology, Miami Univ. School of Medicine, 1600 NW, 10th Av., Miami, Fla. 33136 * Prof. E.A.Kabat, Neurological Institute, The Presbyterian Hospital, 622 West, 168th Street, New York, N. Y. 10016 Dr. L.L.Layton, 670 San Luis Road, Berkeley, Cal. 94707 Dr. B. D. Levine, Department of Medicine, New York University School of Medicine, New York, N. Y. 10016 C Dr. M. H. Loveless, The New York Hospital-Cornell Medical Center, 525 E., 68th Street, New York, N. Y. 10016

Prof. F. Milgrom, Department of Bacteriology and Immunology, SUNY Medical School, Buffalo, N. Y. 14214

VIII Collegium Internationale Allergologicum

*Dr. Z. Ovary, Department of Pathology, New York University School of Medicine, New York, N. Y. 10016 C Dr. M. M. Peshkin, 450 West End Avenue, New York, N Y. 10016 *Prof. S.Raffel, Department of Bacteriology, Stanford University, Stanford, Cal. 94309

Prof. B. H. Waksman, Department of Microbiology, Yale University, 310 Cedar Street, New Haven, Conn. 06510 * Dr. G. L. Waldbott, 2930 West Grand Boulevard, Detroit, Mich. C *Dr. R.P.Woodhouse, 1400 Spear Street, South Burlington, Vt. 05401 *Dr. F.F.Yonkman, Research Department, Ciba Ltd., Summit, N.J.

Sir Henry H. Dale (Hon.)

J. Freeman

M. T. Gutmann

K. Hansen

C.Jimenez-Diaz

J. Maxwell

$*=$ Founder Member

Deceased Members

R. L. Mayer

R. Meier

G. Miescher

H. R. Olivier

C. Prausnitz-Giles

B. Ratner

$\mathrm{C}=$ Corresponding Member

G.A.Rost B.Schick

J.R. S7/8UIRE

R. Tiffeneau H.G.Wolff

$\mathrm{X}$

Contents

Glazer, I.; Ashkenazi, A. and Magora, F. (Jerusalem): Electrosleep Therapy in Bronchial Asthma 163

Glazer, I. (Tel Aviv): Etiologic Factors of Bronchial Asthma in Israel ... 172 Lass, N.; Laurian, L. and Balas, L. (Tel Aviv): Evaluation of Metopiron and ACTH Tests in Prolonged Gorticosteroid Treatment of Chronic Asthma 180 Freedman, B.J.; Meisner, P. and Hill, G. B. (London): A Comparison of the Actions of Different Bronchodilators in Asthma 186

Björklund, B. (Stockholm): Systematic Antigenic Change in Human Carci noma Tissues by Hemagglutination Techniques 191 
Schwartz, Jeanna ; Rutman, Nilly; Vardinon, Nurith and Rosenfeld, E.

(Tel Aviv): Serological Adhesion in Chicken and Mammalian Cultures with

Human Erythrocytes of Different Reactivity 204

Ben-Efraim, S. and Torten, M. (Ness Ziona): Hypersensitivity Reactions in

Experimental Leptospirosis 216

Dukor, P. and Dietrich, F. M. (Basel): Characteristic Features of Immuno-Suppression by

Steroids and Cytotoxic Drugs. Published in Int. Arch. Allergy 34: 32-48 (1968).

Manuscripts not submitted

Quarles Van Ufford, W.J. (Utrecht): Therapeutic Summer Camps for Asthmatic Children

McEwen, L. (London): The Effect in vitro of Grass Pollen Extracts on the Polymorphonuclear Leucocytes of Hay Fever Subjects

Laron, Z. and Doron, M. (Petach-Tikva): Radioimmunoassays: The Correlation between Immunoreactivity and Biological Activity

Levin, S. (Rehovoth): Ataxia Telangiectasia and Malabsorption-An Immune Deficiency Syndrome

Feinberg, J.G. (Stoke Poges, Surrey): Quasy Atopic Conjunctivitis in Guinea Pigs

Fischer, H. (Freiburg i. Br.): On the Possible Role of Lysophosphatides as Mediators in Acute and Delayed Inflammatory Response

Glynn, L. E. (Taplow, Maidenhead, Berks.): The Antigenicity of Collagen and Related

Polypeptides

Schechter, I. (Rehovoth): Competition of Antigenic Determinants in Normal and Tolerant

Animals

Vardinon, M. (Tel Aviv): Mast Cell Sensitizing Antibody and Its Characteristics

Abraham, R. (Carshalton, Surrey): Lysozomes and Mast Cells

Hahn, F.; Giertz, H. and Hernauer, W. (Freiburg i.Br.): Mechanism of the Delayed Anaphylactic

Shock in Guinea Pigs

Transactions of the Collegium Internationale Allergologicum 7th Symposium in Tel Aviv, February 25th-March 1st, 1968 